\title{
School Culture That Supports Graduate Competency Development: A Case Study at SMK PIKA Semarang
}

\author{
Wahyu Noviansyah ${ }^{1, *}$ Itok Dwi Kurniawan ${ }^{2}$
}

\author{
${ }^{1}$ Faculty of Teacher Training and Education, Sebelas Maret University of Surakarta, Surakarta, Central Java 57126, \\ Indonesia \\ ${ }^{2}$ Faculty of Law, Sebelas Maret University of Surakarta, Surakarta, Central Java 57126, Indonesia \\ *Corresponding author. Email: wahyunoviansyah@staff.uns.ac.id
}

\begin{abstract}
SMK PIKA Semarang is a vocational school that has succeeded in shaping graduate competencies that are in line with the world of work's needs. The phenomenon of the excellence of SMK PIKA in shaping graduate competencies cannot be separated from the role of schools' competency culture process. This study aims to explore the concept of school culture at SMK PIKA Semarang that supports the development of graduate students' competency. The research was conducted using a qualitative approach to the type of case study. The data collection process was carried out using in-depth interview techniques, participant observation, and documentation study. The informants consisted of the principal, vice-principal, teachers, and students who were selected purposively. Observations are focused on the behavior of students, teachers, and their interactions in the school environment. The data validity test used triangulation techniques, and data analysis was carried out using the interactive model qualitative data analysis from Miles and Huberman. The results showed that SMK PIKA has a school culture concept rooted in the spirit of 4C (Competence, Compassion, Conscience, Commitment). These values mean that educational activities at SMK PIKA must rely on skills in the areas of expertise (competence), morality (compassion), noble cultural truth values (conscience), and a strong will and determination in carrying out all the principles and the values that apply in the SMK PIKA environment (commitment).
\end{abstract}

Keywords: School Culture, Competence, Compassion, Conscience, Commitment

\section{INTRODUCTION}

The increasingly complex challenges of the world of work require the readiness of Vocational High Schools (SMK) to produce graduates who are competent, adaptive, and able to compete in the job market. The development of information technology impacts changes in thinking and working and work culture and climate [1]. Facing this paradigm shift, the development of competency of Vocational High School (SMK) graduates does not only focus on work skills in carrying out job tasks but needs to strengthen aspects of personality. Aspects of work skills and personality will complement each other to form a complete work competency in facing the 21 st-century world of work.

SMK PIKA Semarang is one of the successful vocational institutions in shaping graduate competencies. Qualified SMK PIKA graduates are inversely proportional to the SMK graduate unemployment phenomenon, which continues to be in the public spotlight. So far, the high number of unemployed SMK graduates is due to the gap incompetence of graduates with the world of work demands. This inconsistency makes SMK graduates not well absorbed in the job market.

In contrast to this perception, SMK PIKA graduates are superior, competent, and globally competitive. It allows PIKA Vocational High School graduates to be absorbed in the job market both as trained workers and entrepreneurs [2-4]. SMK PIKA Semarang's success in shaping graduate competencies can also be seen from the track record of SMK PIKA students' achievement in various skill competitions. SMK PIKA students consistently succeed in winning student competency competitions at the national, regional, and international levels [5-6]. The achievement records can be seen in the following table.

Tabel 1. Table 1. Student Achievement Records of SMK PIKA Semarang

\begin{tabular}{|c|c|c|}
\hline Competition & Year & Achievement \\
\hline 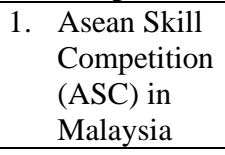 & 2016 & $\begin{array}{l}\text { Gold Medal Cabinet } \\
\text { Making }\end{array}$ \\
\hline $\begin{array}{ll}\text { 2. } & \text { World Skill } \\
\text { Competition } \\
\text { (WSC) in } \\
\text { Brazil }\end{array}$ & 2015 & $\begin{array}{l}\text { Medallion for } \\
\text { Excellence Joinery }\end{array}$ \\
\hline
\end{tabular}




\begin{tabular}{|c|c|c|}
\hline 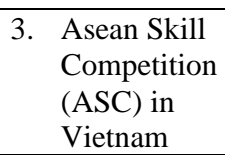 & 2014 & $\begin{array}{l}\text { Gold Medal Joinery, } \\
\text { Silver Medal Cabinet } \\
\text { Making }\end{array}$ \\
\hline $\begin{array}{ll}\text { 4. } & \text { Nasional } \\
\text { Competency } \\
\text { Competition }\end{array}$ & 2013 & $\begin{array}{l}\text { First rank on Joinery } \\
\text { Gold Medal Joinery }\end{array}$ \\
\hline $\begin{array}{l}\text { 5. Asean Skill } \\
\text { Competition } \\
\text { (ASC) in } \\
\text { Indonesia }\end{array}$ & 2012 & $\begin{array}{l}\text { Silver Medal Joinery, } \\
\text { Silver Medal Cabinet } \\
\text { Making }\end{array}$ \\
\hline
\end{tabular}

SMK PIKA's success in developing graduate competencies is inseparable from school culture's role that shapes work character for SMK PIKA students. School culture has a positive effect on students' productive competence [7]. School culture has a strategic role in determining the success of schools in achieving educational goals. Through school culture, the culture of competence and values needed by the world of work can be appropriately internalized by students. Each school is believed to have a unique culture that is inherent and reflected in behavior patterns [8]. Including the uniqueness of the school culture in SMK PIKA can form graduate competencies that are in line with the world of work's values.

The school environment will provide cultural knowledge about understanding, values, and behavior obtained through socialization and enculturation [9]. Behavior, based on values that are upheld and carried out continuously, will shape behavior habits as one of the goals of cultural education is to form students' habits and behavior that are in line with school cultural values [10]. The school culture embedded in every school member will have a progressive effect on the school where the school culture becomes the basis for thinking, speaking, and behaving that will drive school life [11].

Based on the description of this phenomenon, this study aims to reveal how the concept of school culture at SMK PIKA Semarang plays a role in developing graduate competencies. Then what values are contained in the school culture at SMK PIKA and the behavior patterns that reflect these values.

\subsection{School Culture}

School culture is a community interaction in school life, both internal and across groups bound by the rules, norms, morals, and ethics that apply in school. School environment [10]. School culture is classified into three layers [14]. The first layer is the artifact layer, namely the school culture on the outer layer, and can be observed with the five senses. Artifacts are the manifestation of school culture in the form of rituals, symbols, behaviors, and habits at school.

The definition of culture in the context of behavior is a visible phenomenon related to behavior such as patterns of social interaction, including rituals, order, traditional clothing, and artifacts in images and art performances or typical food [9].
The middle layer is the values and beliefs that reflect the behavior and habits of the school community in the form of slogans or jargon that the school wants to embody, such as being diligent at the beginning of intelligence, saving for a creamy base, prioritizing cleanliness, tidiness and beauty (K3) and others. The innermost layer is the assumptions that are believed to be true to form values and beliefs.

In the context of vocational education, habits that are essential and need to be developed in students are habits of thinking and working through repeated training. Three habits that need to be taught to students, namely:

1. Habits to adapt to the work environment

2. Habits in the work implementation process

3. The habit of thinking at work [12]

Work habits will be developed when vocational education provides training with real jobs and not just for training or imitation [13]. The school culture in Vocational High Schools (SMK) needs to be internalized within the community, integrated, and aligned with the school's goals as a vocational education institution to affect the development of student competencies. Schools are conditioned in such a way that values or norms of behavior contribute to building productive competence. Thus, the patterns of student behavior form habits in working under the demands of the work world.

\section{METHODS}

This study aims to explore the school culture in SMK PIKA to find conceptions, values, assumptions, and behavior patterns that support the development of graduate competencies. The positive phenomenon that occurs at SMK PIKA in producing superior graduates can be a reference for best practice (best practice) in developing the competence of SMK students. In order to achieve these objectives, the research approach used is a qualitative case study type. Qualitative case study research is used for research that wants to understand social phenomena indepth [15]. Data collection was carried out by involving oneself and interacting directly with data sources at SMK PIKA Semarang.

Collecting data from informants using interview techniques, participant observation, and document analysis. The informants in this study were selected purposively with the primary consideration that the data sources correctly understood the meaning of the school culture in SMK PIKA. Informants include Principals, teachers, education staff, and SMK PIKA students.

The data analysis technique used qualitative data analysis from Miles and Huberman [16]. Data analysis consists of four stages, namely: data collection (collecting data), data reduction (data reduction), displaying data (display data), drawing conclusions (verification/conclusion). The first 
stage is collecting data from various sources and data collection techniques. The data that has been collected is, then reduced to select relevant data and focus on the research objectives. The data reduction process uses coding analysis by giving code labels to essential statements. The results of data reduction are presented in a

\section{RESULT AND DISCUSSION}

\subsection{The Concept of School Culture in PIKA Vocational High School}

SMK PIKA Semarang is one of eight colleges in Indonesia managed by the Jesuit Union (SJ). The Jesuit Union (SJ) is the name for the clergy of the Catholic religion Jesus union order. The implementation of education at SMK PIKA refers to the Spirit and values of 4C: competence, conscience, compassion, and commitment (D.FS.05, O.FS.02, W.FS.MRS.04, W. FS.05. LKS). The Principal of SMK PIKA said, "we have a passion, namely 4C. Competence hopes that schools here are smart, have smart brains, but if vocational schools are smart, their hands are skilled. The second one is compassion. Compassion is not enough to be smart, we teach our children to care for others, be compassionate. Especially for little people. That compassion does care. The third $\mathrm{C}$, conscience, is a word that describes the honest, the smartest brain, the smartest data visualization table to find the relationship between codes and categories so that the concept of school culture at SMK PIKA is formed. Finally, conclude from the results of data analysis.

heart but all that is done honestly. The 4th $\mathrm{C}$ is the commitment to do it all. That's what we do (W.FS.MRS.74). “

This 4C Spirit is internalized into students through the process of cultivating $4 \mathrm{C}$ values. The actualization and habituation of $4 \mathrm{C}$ values are expected to achieve the educational goals at SMK PIKA, which want to produce graduates competent in the world of work, humanist and virtuous in people's lives. "The Spirit of $4 \mathrm{C}$ will animate all the behaviors that are in it. I personally say it is the Spirit, the Spirit to be achieved, the values to be achieved with the graduates, the $3 \mathrm{Cs}$, competence, compassion, conscience. (W.FS.42.LKS). " The term spirit is in line with Suriasumantri, which states that cultural values are the soul of culture and the basis of all cultural forms [17]. Stolp \& Smith divides school culture into three layers, namely the outer layer that can be observed with the senses (artifacts), the middle layer (values or beliefs), and the inner layer (assumptions) [14]. Referring to this opinion, the depiction of the $4 \mathrm{C}$ cultural concept at SMK PIKA can be seen in the illustrations in Figures 1 and 2 below.

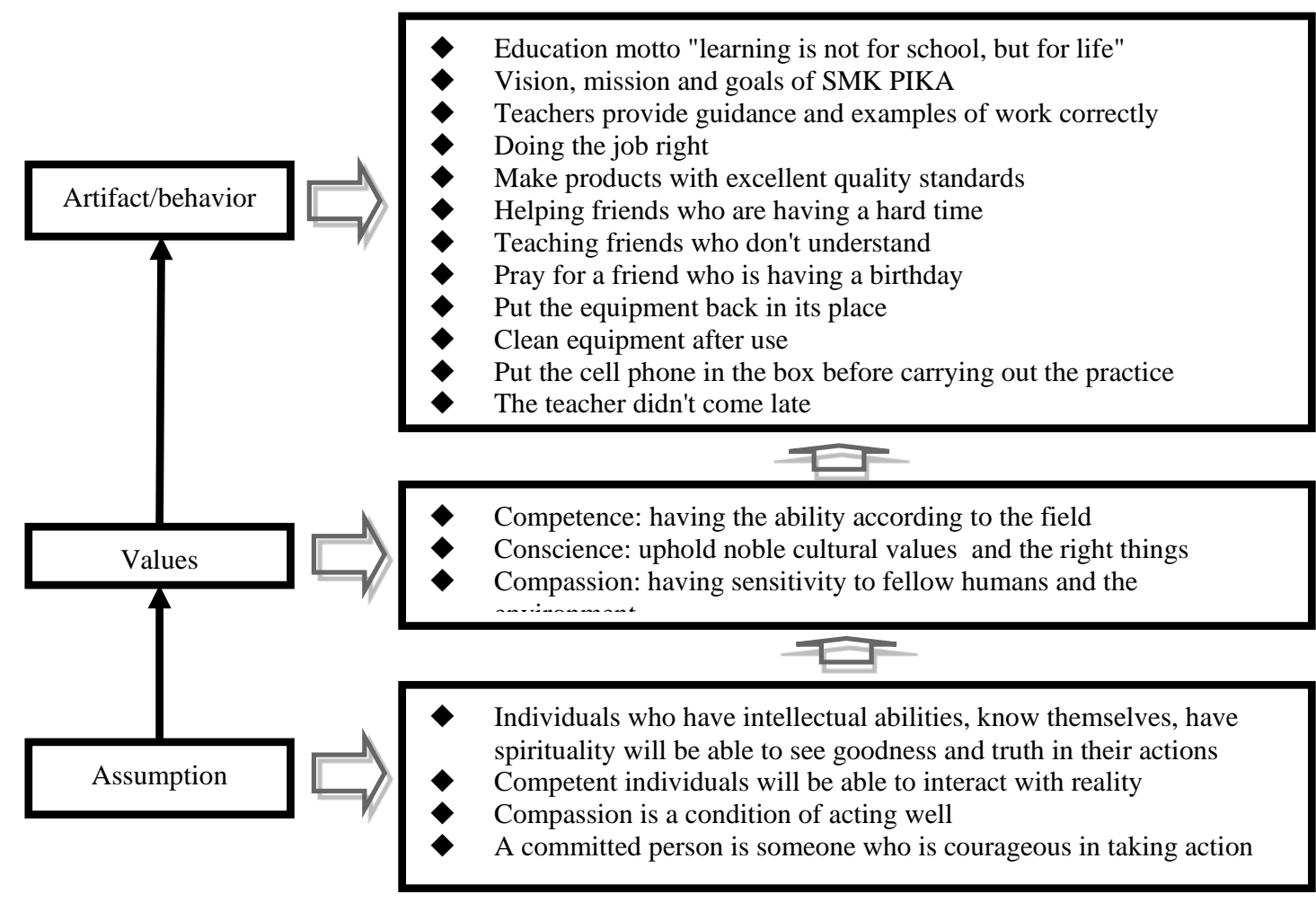

Figure 1. 4C Cultural Layers at SMK PIKA Semarang 


\subsection{Competence Culture}

Cultural competence is a value that emphasizes proficiency in the field. In the context of SMK PIKA, it means ability in the field of furniture engineering. Competence comes from a word in English, which means ability or proficiency. Competence means having the ability and willingness to act [18]. A competent person certainly has the ability or ability to do the job. A competent person can create, understand, and use knowledge and skills in the context of his life to interact with reality [19].

A person is considered competent when he can apply his / her competence to properly carry out job tasks. The competencies needed to carry out work tasks in furniture engineering are taught to students starting from the beginning of the student entering SMK PIKA, following the learning process in class X, XI and XII until students obtain the competency standards expected by the world of work. Students are required to be able to master competencies correctly in order to carry out work assignments effectively. Students are guided to have work habits and think correctly while doing work. Thus, a culture of competence can shape abilities and work habits that align with industry demands.

Cultural competence in the learning process does not only lead to students. Teachers are also required to internalize a culture of competence in themselves. If the culture of competence requires students to have solid skills in furniture, then the teacher must master these skills. An expert in furniture engineering certainly needs to be trained with people who have expertise in furniture engineering. A law applies in vocational education, which says that only teachers who have experience in a job competency can teach that competency well [18]. The experience in question is that the teacher properly and correctly masters the competencies that students want to teach.

\subsection{Compassion Culture}

The compassion culture is a value that emphasizes care and togetherness between fellow humans and the environment. Compassion comes from the English word, which means compassion. Compassion can lead to actions to lessen the distress of others. A person with compassion can develop kindness and care to create justice and solidarity [19]. In meaning, the word "solidarity" can represent the meaning of compassion itself, where solidarity by definition includes the values referred to in the compassion culture, namely a sense of togetherness, care, empathy, altruism as part of the same group.

The school community cannot be separated from individuals' relationships and interactions within groups and across groups. Group internal means relationships and interactions within a group, such as a relationship between teachers, teachers, employees, and students. Then crossgroup means the relationship between groups with each other within the school community's scope, for example, the relationship between teachers and students, teachers and employees, students, and employees. In undergoing interactions between community members within the school's scope, togetherness and solidarity are needed to achieve educational goals. Achieving educational goals without a sense of togetherness and solidarity is difficult to achieve.

The compassion values can foster a cultural spirit of cooperation between parties to help each other in work. Teachers who live the value of compassion always have sincerity, compassion, and care to educate, teach, and train students in the learning process. Students who have compassion in themselves always help their friends' difficulties in learning. Likewise, employees who help teachers and students with administrative tasks so that the value of compassion also fosters a cultural spirit of serving others. All of this leads to harmonizing relationships between all school community members to achieve the expected educational goals.

\subsection{Conscience Culture}

Conscience culture is a school culture that emphasizes noble values and the right things. Conscience culture leads to the formation of the behavior of community members that are in line with noble values so that they are accustomed to acting correctly under applicable norms or rules. Conscience teaches about morality and good personality in developing one's capacity. Capacity needs to be balanced with personality and good morals. The capacity that is not balanced with moral behavior tends to use its ability for actions against the prevailing norms or rules.

Conscience teaches a person to act according to noble values and do the right thing. Conscious people have the intrinsic ability to see truth and goodness in acting [19]. Behaviors under noble values are developed in the educational process, including honesty, discipline, and responsibility.

The inculcation of honesty values in SMK PIKA is carried out by using a religious approach. The religious approach is manifested by reflecting on the actions carried out every day through the examen book. Reflection activities in the form of reflection and conversation with God about all the events experienced during one day at school. Look for the meaning of what was experienced during one day at school. The approach used by SMK PIKA provides the view that the inculcation of honesty values in students needs to be accompanied by an increase in spirituality. Someone who has a high spiritual tendency to behave honestly. It is done with the assumption that all actions and behavior carried out are always supervised by God to act and behave correctly.

Discipline culture is the behavior of obeying and obeying the prevailing rules. Discipline is an attitude or action always to obey the rules [20]. To create a disciplined culture, the school organization needs to clearly describe the rules that apply in the school environment to implement them with full awareness. SMK PIKA creates a 
culture of discipline for students by adopting a disciplined culture that resembles the world of work. The rules are conditioned so that students have disciplinary habits that align with the demands of the world of work.

SMK PIKA in instilling an attitude of responsibility is carried out by enforcing firmness and strengthening of discipline. It provides an understanding that to form a sense of responsibility within oneself needs to be accompanied by assertiveness in implementing rules or regulations.t The implementation of rules that are not accompanied by firmness in imposing sanctions can cause ineffectiveness in their application. Students can tend to ignore school rules and regulations or repeat their mistakes if there is no assertiveness against violations. The things that are done by SMK PIKA in training responsible attitudes include

1. providing sanctions points for each violation;

2. provide a written warning and agreement;

3. do push-ups when dropping tools or workpieces;

4. instructing students to replace equipment that is intentionally or unintentionally lost;

5. return borrowed equipment;

6. give each student a toolbox and equipment.

\subsection{Commitment Culture}

Commitment is an attitude or behavior to carry out all rules, norms, and orders that apply seriously and with full awareness. Commitment means an agreement between parties to do it together. A committed person dares to act [19]. Courage is the willingness to live up to the agreed values together with sincerity.

Commitment to carry out any behavior that reflects these values needs to be balanced with an exemplary attitude. Principals become role models for teachers and employees, and teachers become role models for students' behavior. Teachers will bring cultural and experiential backgrounds into teaching practice, so that teacher behavior in teaching affects the students' culture [9]. Implementing values that are not accompanied by an exemplary attitude makes these values merely a meaningless slogan.

\section{CONCLUSION}

The process of developing competency of graduates at SMK PIKA refers to the concept of cultural competence, conscience, compassion, and commitment (4C). Spirit 4C becomes the Spirit in the education process at SMK PIKA. This 4C Spirit is internalized into students through the process of cultivating $4 \mathrm{C}$ values. These values mean that educational activities at SMK PIKA must rely on skills in the areas of expertise (competence), morality (compassion), noble cultural truth values (conscience), and a strong will and determination in carrying out all the principles and the values that apply in the SMK PIKA environment (commitment). The actualization and habituation of $4 \mathrm{C}$ values are expected to achieve educational goals at SMK PIKA, which want to produce competent, humanist, and virtuous graduates in the world of work and social life. It is the provision of excellence for SMK PIKA graduates to compete and be absorbed in the job market, which requires a competent workforce and strong character.

\section{ACKNOWLEDGMENT}

This work was supported by PIKA Vocational High School (SMK) Semarang and Sebelas Maret Surakarta of University to complete this research.

\section{REFERENCES}

[1] F. Boutin, C. Chinien, L. Moratis, P.V. Baalen, Overview: Changing Economic Environment and Workplace Requirements; Implications for ReEngineering TVET for Prosperity. In Rupert Maclean, David Wilson, Chris Chinien (Eds). International Handbook of Education for the Changing Worl of Work, Springer, Bonn, 2009.

[2] T, Setiyawati, Implementation of Base Practice in Management Practice Learning at SMK PIKA Semarang in Preparing Graduates who are Ready to Work and have Global Competitiveness. Jurnal Invotec, 2013, pp. 179

DOI:https://doi.org/10.17509/invotec.v9i2.4879.

[3] B, Sugestiyadi, Disertation Report, UNY, Yogyakarta, 2016. DOI:https://eprints.uny.ac.id/31753/

[4] Adriyanto, SMK PIKA SMK PIKA Semarang: School or Factory?, 2012, DOI:http://1ptk.blogspot.co.id/2012/09/smk-pikasemarang-sekolah-atau-pabrik.html

[5] W, Noviansyah, P, Sudira, The Praxis of ProjectBased Learning at PIKA Vocational Secondary School ,Jurnal Pendidikan Vokasi, Semarang, 2020. DOI: https://doi.org/10.21831/jpv.v10i1.29032

[6] Berita Jateng, PIKA Vocational School Students Join World Skill, Competition in Brazil, 2015. DOI: http://beritajateng.net/siswa-smk-pika-ikuti-world-skillcompetition-di-brasil/

[7] Ramli, The Influence of School Culture on Productive Competencies of Students of West Sumatra State Vocational High School, Jurnal Cakrawala Pendidikan, pp.307-314, 2013. DOI: https://doi.org/10.21831/cp.v0i2.1489

[8] C.R,Wagner, Leadership for an improved school culture. How to assess and improve the culture of your 
culture, Kentucki School Leader, Kentucko,2004. DOI: http://www.schoolculture.net/ kyschoolleaderfall04.pdf.

[9] E.R, Hollins, Culture in School Learning: Revealing Deep Meaning, Routledge, New York, 2008.

[10] Research and Development Agency, Development of National Culture and Character Education, Ministry of Education and Culture of the Republic of Indonesia, Jakarta, 2010.

[11] Barnawi, M. Arifin, Managing Entrepreneurship-Based Schools, Ar-Ruzz Media, Yogjakarta, 2016.

[12] Dharma, et.al, 1st Century Vocational School Teacher Challenges, Ministry of Education and Culture of the Republic of Indonesia, Jakarta, 2013.

[13] C.A, Prosser, T.H, Quigley, Vocational Education In a Democracy, American Technical Society, Chicago 1950.

[14] Jumadi,School Culture and Contextual Learning in KBK, Papers presented in the School Culture Development Training, Sleman, 2006.

[15] K.R, Yin, Case Study Research: Design and Methods, USA, 2009.

[16] M.B, Miles, A.M, Huberman, Qualitative Data Analysis, Sage, California, 1994.

[17] J.S, Suriasumantri, Philosophy of Science: A Popular Introduction, Pustaka Sinar Harapan, Jakarta, 2013.

[18] P, Sudira, XXI CENTURY TVET: Philosophy, Theory, Concepts, Vocational Learning Strategies, UNY Press, Yogyakarta, 2016.

[19] SJ, Educatio, Jesuit Education Aims to Human Excellence: Men and Women of Conscience, Competence, Compassion and Commitment, Secretariat for Education, Roma, 2013. 